\title{
Finnish people's attitudes towards biomedical research and its sponsorship
}

\author{
ELINA HEMMINKI, AARO TUPASELA, PIIA JALLINOJA, ARJA R. \\ ARO, KAROLIINA SNELL, AND SINIKKA SIHVO ${ }^{1}$
}

\begin{abstract}
The purpose of the research was to study Finnish people's attitudes towards biomedical research and whether the research sponsor makes a difference to those attitudes. A survey questionnaire was sent to a random sample of 25-64 years old. Respondents had a positive attitude towards biomedical research and there were only small variations by population group. When asked whether one's own clinical blood samples could be used in scientific biomedical research, 84 per cent of the respondents would allow it. The most important reasons for giving routinely collected samples to a biobank were altruistic. Attitudes were strongly dependent on the sponsor of the research. Domestic research was looked at more positively than international research. Whether research was made by a public or private actor had less impact. The results suggest that people want to be research participants to help such research of their own free will, and to choose whom they help. This has an impact on the way participants are informed, on the criteria used by ethics committees and other research regulators, and also on transparency and access to research results.
\end{abstract}

\section{Introduction}

A common ethics-based view of biomedical research participation, culminating in informed consent, is that participants' own interests are primary. ${ }_{5}^{2,3,4}$ For each participant, the expected benefit-harm ratio should be positive. ${ }^{5}$ Our experience of the advice on what information to give to the research subject as part of obtaining informed consent suggests that those building ethical norms assume that potential research subjects are interested mainly in their own well-being, and societal interests or research policy play less of a role. However, earlier literature on research participants' reasons for joining medical research shows that the reasons are partly altruistic, though many also expect personal benefit and some feel it to be a duty to participate. $^{6,7,8,9}$

In intervention research that has a high risk of physical harm, the focus on subject's well-being in informed consent is crucial. However, medical research is often based on blood and tissue samples, images and written documents. Data or samples already collected either in routine clinical practice or for previous research may be used. In such research, physical harm for subjects is a lesser concern and the informed consent weighs personal ownership, privacy and altruistic interests against research and societal interests. ${ }^{10}$

The motivation of participants to support research and participate has also been shown to be dependent on research sponsorship. ${ }^{11}$ Critchley has argued that people's trust in publically funded research is greater, because of to a greater level of trust in publically 
funded scientists as against privately-funded scientists. ${ }^{12}$ The public/private dichotomy is, however, increasingly problematic in biotechnology because of the blurring of the boundary between publically and privately sponsored research, ${ }^{13}$ making the distinction between the two categories problematic.

When the Finnish Ministry of Social and Health Affairs started to prepare a law governing biobanks, the Finnish Funding Agency for Technology and Innovation (TEKES) financed us to carry out a survey on laypeople's opinions of biobanks. ${ }^{14}$ Data from that survey was used to investigate people's general attitudes towards biomedical research and whether the research sponsor made a difference to their attitudes. Specific attitudes towards biobanks and informed consent have already been reported, ${ }^{15}$ and determinants of people's reasons for participating in research will be reported separately (Sihvo et al. 2010 unpublished manuscript).

\section{Methods}

A survey questionnaire was mailed to a random sample of Finnish-speaking residents in Finland aged between 25-64 $(n=2400)$ in 2007. After one reminder, a total of 1192 (50 per cent) responses were received. Four respondents without background information are excluded from this paper. The questionnaires did not ask for the respondent's name, although they contained a number that was used to identify nonrespondents for the second mailing of the questionnaire.

The questionnaire was sent jointly in the name of STAKES (the National Research and Development Centre for Welfare and Health, now merged into the National Institute for Health and Welfare) and the Department of Sociology, University of Helsinki. The cover letter referred to the expert group in the Ministry of Social Affairs and Health and stated the purpose of the survey to be the mapping of citizens' opinions. The questionnaire contained 28 questions focusing on opinions about biobanks and on the use of blood and tissue samples. The key questions (translated by the authors) used in this paper are given in Appendix 1.

Table 1. Background characteristics of the respondents by age, $\%$

\begin{tabular}{|l|l|l|l|l|l|}
\hline & $25-34$ & $35-44$ & $45-54$ & $55-64$ & Total \\
\hline (number, \%) & $(238$, & $(257$, & $(348$, & $(345$, & $(1188$, \\
& $20.0)$ & $21.7)$ & $29.3)$ & $29.0)$ & $100)$ \\
\hline Basic education & & & & & \\
\hline$<9 \mathrm{yr}$ & 0.8 & 1.6 & 28.7 & 50.0 & 23.0 \\
\hline middle level & 36.1 & 44.8 & 36.2 & 26.4 & 35.0 \\
\hline high school & 62.6 & 52.5 & 34.2 & 23.48 & 41.0 \\
\hline Gender: woman & 62.45 & 59.1 & 53.0 & 53.9 & 56.5 \\
\hline Have children & 42.9 & 70.8 & 80.8 & 86.1 & 72.6 \\
\hline $\begin{array}{l}\text { Has worked in health } \\
\text { field }\end{array}$ & 20.2 & 19.1 & 18.4 & 14.5 & 17.8 \\
\hline Total & 100 & 100 & 100 & 100 & 100 \\
\hline
\end{tabular}

The results were first analyzed by age-groups. Statistical significance was tested by chi-square or t-test, while logistic regression was used to study the results by gender

Genomics, Society and Policy, Vol.5, No.2 (2009) ISSN: 1746-5354

(C) ESRC Genomics Network. 
and education, adjusting for age; odds ratios and 95 per cent confidence intervals were calculated. Table 1 gives the background characteristics of the respondents. The distribution of education by age reflects the change in the national education system in the 1970s. Among the younger age groups, more women than men responded.

Compared to the original random sample, respondents were relatively similar in regard to gender (women 51 per cent of the original sample, 57 per cent of the respondents) and age-structure (respectively 22 per cent and 20 per cent of those aged 25-34; 24 per cent and 22 per cent of those aged 35-44; 27 per cent and 29 per cent of those aged 45-54; and 26 per cent and 29 per cent of those aged 55-64).

\section{Results}

General attitudes by age

In an attitudinal question with five options ranging from mainly positive to mainly negative (see question 3 in the Appendix), most respondents said they had a positive or quite positive attitude towards biomedical research -see Table 2 . The answers were very similar in different age groups.

Table 2. Attitudes towards biomedical research and research regulation, by age, $\mathbf{\%}^{\mathbf{a}}$

\begin{tabular}{|l|l|l|l|l|l|l|}
\hline & $25-34$ & $35-44$ & $45-54$ & $55-64$ & Total & p-value \\
\hline (number) & $(238)$ & $(257)$ & $(348)$ & $(345)$ & $(1188)$ & \\
\hline $\begin{array}{l}\text { (Q3) Positive attitude } \\
\text { towards, \% }\end{array}$ & & & & & & \\
\hline genetic research & 92 & 88 & 89 & 87 & 89 & .239 \\
\hline diagnostic research & 96 & 96 & 96 & 92 & 95 & .018 \\
\hline $\begin{array}{l}\text { development of new } \\
\text { drugs }\end{array}$ & 97 & 97 & 96 & 97 & 97 & .916 \\
\hline $\begin{array}{l}\text { development of new } \\
\text { vaccines }\end{array}$ & 97 & 95 & 97 & 96 & 96 & .428 \\
\hline $\begin{array}{l}\text { (Q5) Use of own clinical } \\
\text { blood samples for } \\
\text { research } \text {, yes, \% }\end{array}$ & 82 & 82 & 84 & 85 & 84 & .924 \\
\hline $\begin{array}{l}\text { (Q19) Duty to } \\
\text { participate in biobanks }{ }^{\mathrm{d}}, \\
\text { yes, \% }\end{array}$ & 19 & 26 & 29 & 33 & 27 & .001 \\
\hline $\begin{array}{l}\text { (Q1) Is concept "ethics } \\
\text { committee" familiar, } \\
\text { yes, \% }\end{array}$ & 53 & 64 & 51 & 52 & 54 & .005 \\
\hline
\end{tabular}

a: $\mathrm{Q}=$ question number, questions are given in Appendix

b: Positive + quite positive (alternatives $1+2$ )

c: From a case description

d: From a series of claims

The questionnaire presented a hypothetical case enquiring about the use of one's own blood sample collected during a clinical patient contact (see Appendix). We asked whether the person would allow that sample to be used in scientific research studying the health impact of genetic and other exposures. The research design was said to include anonymous (coded) analysis, register linkages and storing the data in a public 
research institute. Of the respondents, 84 per cent would allow the sample to be used in research (Table 2). Only 6 per cent said they would not allow their sample to be used and 11 per cent did not know or did not answer. There was no variation by age.

The respondents were asked whether, from a list of concepts and institutions, the concept of "ethics committee" was familiar. About half (55 per cent) had heard of an ethics committee (Table 2), but only 15 per cent said they knew of its functions.

The questionnaire included a section about biobanks, giving a definition of a biobank (see Appendix). People's motivation to (potentially) participate in biomedical research was studied by a question on their most important reasons to allow their own routinely collected samples to be given to a biobank, which could then be used in research and to develop new treatment methods (question 15 in the Appendix). The most frequently endorsed reasons for giving permission to use the samples were 'promotion of medicine' (91 per cent) and 'benefits for future generations' ( 82 per cent). About half (52 per cent) expected 'personal benefit' (to learn their own risks). 'For the sake of increasing the international competitiveness of Finnish researchers' gained some support ( 29 per cent), but 'promotion of business' received hardly any ( 3 per cent). Nine per cent chose the option of thinking it to be a 'duty'. The answers were similar by age, except for 'helping Finnish researchers', which gained popularity with increasing age (16 per cent in the youngest age group and 41 per cent in the oldest).

A quarter (27 per cent) agreed with the claim that it was people's duty to give their sample to a national biobank, because it would benefit all people (question 19c in the Appendix - see Table 2). The rest said no (41 per cent), did not know or did not answer (32 per cent). Older people were more likely than younger people to agree that it was a duty to give their samples to a biobank (Table 2).

\section{Importance of the sponsor}

In regard to the hypothetical case, people were asked whether they would allow their samples to be used for research to develop new drugs or procedures in a joint development project with industry (question 6, Appendix): 75 per cent said yes (Table 3 ). The proportions saying yes were very similar in the different age groups. Only 9 per cent said explicitly "no" and the rest (16 per cent) could not take a stand.

The respondents were asked for which type of research they would allow their samples held in a national biobank to be used (Question 17, Appendix). More people would allow their samples to be used for research in Finland than for international research (Table 3). There was little difference whether it concerned medical research in general in a public research institute or therapy development in a drug/biomedical firm. The proportion of people who said they would not give their samples for research reflected a similar bias towards Finnish research: 6 per cent for medical research in public institutes, 4 per cent for therapy development in Finnish firms, 16 per cent for international medical research and 20 per cent for therapy development in international firms. The rest said they weren't sure or would not give their samples to 
a national biobank at all (the proportions for the different alternatives varied between 14 and 33 per cent.

Table 3. Variation of attitudes by research institute/sponsor, by age, $\%^{\text {a }}$

\begin{tabular}{|c|c|c|c|c|c|c|}
\hline & $\begin{array}{l}25- \\
34\end{array}$ & $\begin{array}{l}35- \\
44\end{array}$ & $\begin{array}{l}45- \\
54\end{array}$ & 65 & Total & $\begin{array}{l}\mathrm{p} \text { - } \\
\text { value }\end{array}$ \\
\hline (number) & $(238)$ & (257) & (348) & (345) & (1188) & \\
\hline $\begin{array}{l}\text { (Q6) Use of own samples for joint research } \\
\text { with industry, yes, } \% \text { b }\end{array}$ & 73 & 73 & 75 & 78 & 75 & .726 \\
\hline \multicolumn{7}{|l|}{$\begin{array}{l}\text { (Q17) Use of own samples in biobanks for, } \\
\text { yes, \% }\end{array}$} \\
\hline $\begin{array}{l}\text { medical research in (Finnish) public } \\
\text { institutes }\end{array}$ & 81 & 78 & 79 & 75 & 78 & .329 \\
\hline international medical research & 53 & 47 & 49 & 48 & 49 & .355 \\
\hline therapy development in Finnish firms & 72 & 78 & 80 & 79 & 78 & .021 \\
\hline $\begin{array}{l}\text { therapy development in international } \\
\text { firms }\end{array}$ & 42 & 38 & 42 & 46 & 43 & .360 \\
\hline \multicolumn{7}{|l|}{$\begin{array}{l}\text { (Q10) Use of old clinical samples without } \\
\text { consent for, yes, \% }{ }^{\mathrm{d}}\end{array}$} \\
\hline medical research in public institutes & 68 & 64 & 70 & 69 & 68 & .324 \\
\hline therapeutic research in Finnish firms & 55 & 64 & 66 & 69 & 64 & .001 \\
\hline $\begin{array}{l}\text { therapeutic research in international } \\
\text { firms }\end{array}$ & 31 & 30 & 41 & 43 & 37 & .000 \\
\hline \multicolumn{7}{|l|}{ (Q2) Very high or rather high trust on } \\
\hline universities, $\%$ & 81 & 79 & 78 & 69 & 76 & .004 \\
\hline National Public Health Institute & 49 & 53 & 52 & 45 & 49 & .165 \\
\hline Finnish drug firms & 59 & 56 & 48 & 46 & 51 & .004 \\
\hline International drug firms & 34 & 26 & 25 & 25 & 27 & .070 \\
\hline Private drug research firms & 31 & 23 & 22 & 22 & 24 & .051 \\
\hline
\end{tabular}

a: $\mathrm{Q}=$ question number, questions are given in Appendix

$\mathrm{b}: \mathrm{n}=1182$

c: $\mathrm{n}=1115-1159$

$\mathrm{d}: \mathrm{n}=1132$

When asked whether clinical samples stored in a biobank could be used for research without asking permission from the patient (question 10 Appendix), 68 per cent indicated that they would permit this for medical research in public institutes (such as universities or hospitals; see Table 3). The question did not define domestic research, but the formulation of the question implicitly suggested domestic research. Almost as many (64 per cent) would allow usage for developing drugs or other treatments by a Finnish drug or biotechnology firm. Far fewer (37 per cent) would allow their samples to be used for therapy development in international firms. The attitudes towards use of clinical samples in medical research in public institutes were similar across the age range (Table 3). Older people had somewhat more positive attitudes towards therapy development both in Finnish and international firms.

In a separate question (Question 2, Appendix) we asked about trust in various institutions, including those shown in Table 3. Most people said they trusted 
universities (Table 3 ) and public hospitals (73 per cent; not shown in the table). The least trust was expressed in international pharmaceutical firms and private drug research firms; Finnish pharmaceutical firms were in between. People in the oldest age group were the most likely to choose a "cannot say" option; otherwise the age differences in regard to public institutions were small. Younger people had somewhat more trust in commercial actors. Of those not choosing the trust-option, most chose "cannot say" while low trust (very or quite low) was chosen less frequently: 5 per cent for universities, 10 per cent for the national public health institute, 15 per cent for Finnish pharmaceutical firms, 20 per cent for private drug research firms, and 22 per cent for international pharmaceutical firms.

Gender and education

Tables 2-3 show results by age. We also studied whether attitudes varied by gender and education. These (unadjusted) cross-tabulations showed that men's and women's responses were similar (data not shown). Likewise, the responses varied only a little by education (Table 4). People who had undertaken higher education were more likely to allow their samples to enter a biobank to be used for medical research in (Finnish) public institutes and international medical research (Question 17 Appendix). However, the pattern between the different uses remained similar across all educational groups, with respondents favoring Finnish users over international ones.

Table 4. Variation of attitudes by education: proportion of respondents agreeing to their biobank samples to be used for different purposes; age-adjusted odds ratios (OR) (95\% confidence limits)

\begin{tabular}{|l|l|l|l|}
\hline & $\begin{array}{l}\text { high } \\
\text { school }\end{array}$ & middle level & $<9$ years \\
\hline$(\mathrm{n})$ & $(278)$ & $(418)$ & $(484)$ \\
\hline $\begin{array}{l}\text { Medical research in Finnish public } \\
\text { institutes }\end{array}$ & 1.00 & $0.71(0.52-0.98)$ & $0.59(0.40-0.86)$ \\
\hline International medical research & 1.00 & $0.76(0.58-0.99)$ & $0.62(0.44-0.87)$ \\
\hline Therapy development in Finnish firms & 1.00 & $1.22(0.90-1.67)$ & $0.91(0.62-1.35)$ \\
\hline $\begin{array}{l}\text { Therapy development in international } \\
\text { firms }\end{array}$ & 1.00 & $1.02(0.78-1.34)$ & $1.06(0.75-1.49)$ \\
\hline
\end{tabular}

Age-adjustment had little effect on the results by gender and education. Men's and women's responses were relatively similar, but some indicators suggested more support for biomedical research among men than women. If there were differences by education, people who had been through higher education tended to have more favourable attitudes.

\section{Discussion}

This population-based survey among Finnish adults showed a generally positive attitude towards biomedical research, with little variation by population groups but a strong variation according to who were the sponsors of the research. Domestic research was looked at more positively than international research. Whether research was undertaken by a public or private actor had less impact.

Genomics, Society and Policy, Vol.5, No.2 (2009) ISSN: 1746-5354

(C) ESRC Genomics Network. 
Any interpretation of our results should take into account the unfamiliarity of the respondents with the topic, and the relatively low response rate. The main focus of the survey was biobanks. The relatively large number of people choosing "do not know" and "cannot say" options in regard to the explicit question eliciting whether people were familiar with the term 'biobank' suggest that the world of biomedical research is not very familiar to Finnish laypeople. Nine per cent of the respondents reported that they knew what a biobank was, 45 per cent had heard about it, but did not know how it operated, and 46 per cent did not know what it was. ${ }^{16}$ However, we anticipated this and most questions (all referred to in this paper) were formulated in such a way that they measured attitudes and did not require exact prior knowledge. Furthermore, explanations of terms were given when appropriate.

Only half of the people approached responded. A similarly low response rate was found in a population survey in Sweden. ${ }^{17}$ Even though the gender and age distributions were relatively similar to the target sample, the respondents may have differed by other characteristics relating to attitudes towards biomedical research. The low response rate may also indicate that the question of biobanks and the use of (already collected) samples in research are not major issues to laypeople.

The respondents were very positive towards biomedical research that was aimed at developing new medical technology (diagnostics, drugs and vaccines). That extended also to genetic research. Furthermore, most were willing to let their own clinical samples be used for later research, if asked. Previous studies have also found that most people do not object to the use of their clinical samples for research. ${ }^{18,19}$ However, the low proportion of respondents in our study who considered it to be a duty to participate in biobanks, rather than doing it to benefit future generations or research, is in contrast to an earlier Japanese study in which participants frequently expressed an obligation to participate. ${ }^{20}$

Stated reasons for giving blood samples to a biobank were more often altruistic than directly self-beneficial, but it was considered as "a favor to society" rather than a duty. That altruistic motives are more common has been found previously in clinical trials in Finland. ${ }^{21}$ In another study, most Finns considered genetic testing to be acceptable because of the potential efficiency savings for society in treating patients, ${ }^{22}$ while studies in Scotland have shown that participation in biobank research has been motivated by personal interests in genealogy and identity. ${ }^{23}$

Several questions indicated that the respondents were not indifferent to who was carrying out the research. Roughly, the dividing line was between Finnish (domestic) and international sponsors, rather than between public and private sponsors. Research by Finnish sponsors was looked at more favourably than that by international sponsors, even though we had used the neutral words "Finnish" and "international" rather than "domestic" and "foreign" This pattern was repeated when trust in different institutions was asked about. In an earlier study on genetic databases in Sweden, respondents were more trusting towards public than private institutions that handled and collected genetic material. ${ }^{24}$ 
The distinction between domestic and international research is certainly blurred, ${ }^{25}$ due to joint projects and to the multinational ownership of firms. Furthermore, research applicability is not tied to the country of research: innovations made in one country can be used in all countries. Perceptions are likely to be crucial. Thus, trust may not relate to the actual worthiness of the researchers in one's own country, but to the fact that they live in your own country. Our survey cannot explain the higher trust in domestic research, but it may relate to a feeling of control. The greater trust in Finland in Finnish researchers has previously been found in regard to genetics research ${ }^{26}$ and to the SARS-epidemic. ${ }^{27}$ In general, Finns still trust society to work for their benefit and social capital is high. ${ }^{28}$ Participating in biobanks and biomedical research can be regarded as a contribution to the promotion of national public health. This links the altruistic motivation to domestic sponsorship - expectations that Finnish research will further national public health more than will international research.

Earlier studies from Australia and Sweden have reported, unlike our study, that people look more favorably on research in public rather than in private institutions. ${ }^{29}$ No previous studies on how people differentiate between domestic and international research were found. But in a later study in Finland using focus group interviews, differences did emerge in relation to responses. ${ }^{30}$ Clearly only further study in other countries will clarify whether this is a Finnish peculiarity or a more general view.

Our results suggest that people want to choose whether to be research participants, and to choose whom to help. The importance of choice has also been reported in earlier research from Scotland. ${ }^{31}$ This gives a different view from some currently accepted principles of medical ethics, which emphasize the protection of the research participants, and the benefits the participants may receive from a study. Participants' desire for choice has an impact on the way participants are informed and in the criteria used by ethics committees and other research regulators. If participants' usual common motive is altruistic, but selective, then data relevant to that should be provided in patient recruitment leaflets. Research participants may want honest and detailed information about the purpose and assumed value of the research or data collection - who are the researchers and sponsors, and what are their relations - as well as whether the results are made available for the common good. To have more control, research participants are likely to expect transparency in actions and access to research results. Whether such an approach also influences the number of people wanting to join research remains to be seen. ${ }^{32}$

\section{Acknowledgements}

The survey, on which the study is based, was paid by an unconditional grant from TEKES (Finnish Funding Agency for Technology and Innovation) to the University of Helsinki. 


\section{Appendix 1. Questions used in the study.}

Q1 Are the following institutions or concepts familiar to you? No; have heard, but do not know what they do; yes

Ministry of Social Affairs and Health (STM)

National Public Health Institute (KTL)

The Social Insurance Institution (KELA)

STAKES

National Authority for Medicolegal Affairs (TEO)

Biobanks

Research ethics committee

Q2 Below, a number of institutions that conduct medical research, develop medicines or offer medical and healthcare services are listed. How much trust do you have towards them? Very high; quite high; hard to say; quite low; very low; I don't know them.

Universities

Public hospitals

Public health care centers

Private healthcare

National Public Health Institute

\section{STAKES}

Finnish pharmaceutical companies

Private pharmaceutical companies

International pharmaceutical companies

Q3 What is your attitude towards the following types of research? Mostly positive; quite positive; hard to say; quite negative; mostly negative.

Research on human genetics/ genes

Development of diagnostics

Development of new medications

Development of new vaccines

Hypothetical case 1. (used in questions 5 and 6): In the following a hypothetical situation during a routine visit to a doctor is presented. How would you act in that situation?

"Let's assume that a blood sample is taken from you during a routine visit to a doctor. The nurse asks you whether the sample can also be used for scientific research. The sample is given a code number. All the information from the samples is recorded. With the aid of the code number and your personal ID number the recorded information can be connected to your health records and heath register data. A public research institute is responsible for storing these data. The code and the personal ID number are stored in a safe. The data will be used to study how genes and other factors influence health. The researchers do not know from whom the data were derived. 
Q5 Would you give permission for the sample to be used in research? Yes; no; can't say; explanation

Q6 Sometimes researchers collaborate with companies to develop new medicines and treatment methods. Could the sample taken from you be used for such collaboration? Yes; no; can't say

Definition of biobank (given before Q8: What is a biobank?) Blood and other tissue samples are called biological samples. A biobank can be formed from these kinds of biological samples. In the biobank, other information can be added to the samples; such information can be of persons' health, health behavior, living habits or care they have received. Samples in a biobank are used in medical research and to develop drugs and other care methods.

Q10 Health care is required by law to store samples taken for diagnostic purposes. It has been estimated that millions of samples have accumulated in the archives of hospital districts. For which purposes could these old samples be used without asking for patients' consent? Yes ; no ; can't say

Only for the original purpose (for diagnosis)

Medical research in public institutions (such as universities and public hospitals)

For solving crimes

For determining family relations

For developing medicines and treatments in Finnish pharmaceutical and biotechnical firms

For developing medicines and treatments in international firms

Hypothetical case 2 (used in questions 15 and 17). Think of a situation when a national biobank is being planned to be founded in Finland. It would collect samples of Finns originally taken for diagnosis and research. Information from health and other registers would be connected to these samples. The possibility to combine the sample and personal information increases the value of the samples in research. The samples and their data could later be used to develop medicines and treatment methods.

Q15 If you would give permission to use your samples, what would be your most important reasons for doing so? (You may choose more than one option.)

Promotion of medicine

Duty

Identification of my risks

Increasing international competitiveness of Finnish researchers

Benefits for future generations

Promotion of business

I would be afraid to decline

Other reason, what? 
Q17 For what purposes could your samples in the biobank be used? Yes ; no ; can't say ; I would not give my samples

All types of medical research in public institutions (such as universities and public hospitals)

International medical research

For developing medicines and treatments in Finnish pharmaceutical and biotechnical firms

For developing medicines and treatments in international firms

Q19 In the following we present some claims. Circle the answer which best describes your opinion. Yes; no; can't say

The information from my sample can be connected with my other health information (e.g. to my medical records).

My samples can be used in future research, which was not anticipated at the time of taking the sample.

People have a duty to donate their samples to the national biobank, because the benefits will accrue to all.

People must have the right to check for which type of research their samples are being used.

Dead peoples' samples can be used without specific permission.

If the parent consents on behalf of his/her child to use the child's samples, a new permission from the child has to be obtained when he/she turns 18 years. 
${ }^{1}$ National Institute for Health and Welfare (THL), Helsinki, Finland. Correspondence to: elina.hemminki@,thl.fi

${ }^{2}$ N.C. Manson et al. 2007. Rethinking Informed Consent in Bioethics. Cambridge University Press, Cambridge.

${ }^{3}$ J. Sugarman et al. Empirical research on informed consent. An annotated bibliography Hastings Cent Rep 1999; 29(1):S1-42.

${ }^{4}$ T. Beauchamp and R.R. Faden. 1986. A History and Theory of Informed Consent. Oxford.

${ }^{5}$ D.B. Resnik. Exploitation in biomedical research. Theor Med Bioeth 2003; 24(3):233-59.

${ }^{6}$ J.M. Trauth et al. Public attitudes regarding willingness to participate in medical research studies. $J$ Health Soc Policy 2000;12(2):23-43.

${ }^{7}$ R. Tutton. They want to know where they came from: Population genetics, identity, and family genealogy. New Genet Soc 2004; 23(1):105-20.

${ }^{8}$ P.S. Hietanen et al. A short communication trial for physicians improves the quality of patient information in a clinical trial. Acta Oncol 2007; 46:42-8.

${ }^{9}$ A. Asai et al. Focus group interviews examining attitudes towards medical research among the Japanese: a qualitative study. Bioethics 2006; 18(5):448-70.

10 A. Tupasela. 2008. Consent Practices and Biomedical Knowledge Production in Tissue Economies. Department of Sociology, Helsinki University Print, Helsinki. Research reports 256.

${ }^{11}$ K.E. Eriksson et al. 2007. A sociological perspective: Public perceptions of privacy and their trust in institutions managing and regulating genetic databases. In The Ethics and Governance of Human Genetic Databases. M. Häyry, ed. Cambridge, Cambridge University Press:43-89.

${ }^{12}$ C.R. Critchley. Public opinion and trust in scientists: The role of the research context, and the perceived motivation of stem cell researchers. Public Underst Sci 2008; 17:309-27.

${ }^{13}$ D. Chalmers and D. Nicol. Commercialization of biotechnology: public trust and research. Int $J$ Biotechnol 2004; 6:116-33.

${ }^{14}$ S Sihvo et al. Väestö, biopankit ja lääketieteellinen tutkimus - Suomalaisten suhtautuminen lääketieteellisten näytteiden käyttöön [People, biobanks and medical research - attitudes of Finns towards the use of medical collections]. Stakes Työpapereita 18/2007, 978-951-33-1967-0. Available at http://www.stakes.fi/FI/Julkaisut/verkkojulkaisut/tyopapereita07/index.htm

${ }^{15}$ A. Tupasela et al. Attitudes towards biomedical use of tissue sample collections, consent, and biobanks among Finns. Scand J Public Health, published on November 11, 2009 as doi: $10.1177 / 1403494809353824$.

16 Ibid.

${ }^{17} \AA$ A. Kettis-Linblad et al. Genetic research and donation of tissue samples to biobanks. What do potential sample donors in the Swedish general public think? Eur J Public Health 2005; 16:433-40.

${ }^{18} \mathrm{~S}$. Treweek et al. Public attitudes to the storage of blood left over from routine general practice tests and its use in research. $J$ Health Serv Res Policy 2009; 14(1):13-21.

${ }^{19}$ R.J. Bryant et al. Ownership and uses of human tissue: What are the opinions of surgical in-patients? $J$ Clin Pathol 2008; 61:322-6.

${ }^{20}$ Asai et al, op. cit. note 9.

${ }^{21} \mathrm{P}$. Hietanen et al. Information and communication in the context of a clinical trial. Eur J Cancer 2000; 36(16):2096-104.

${ }^{22}$ A.R. Aro et al. Acceptance of genetic testing in a general population: age, education and gender differences. Patient Educ Couns 1997; 32:41-9.

${ }^{23}$ Tutton, op. cit. note 7.

${ }^{24}$ Eriksson et al., op. cit. note 11 .

${ }^{25}$ Chalmers and Nicol, op. cit. note 13.

${ }^{26}$ P. Jallinoja and A. Aro. Knowledge about genes and heredity among Finns. New Genet Soc 1999; 18(1):101-10.

${ }^{27}$ A.M. Vartti et al. SARS ja suomalaisten tyytyväisyys viranomaisiin ja mielipiteet tarpeellisista kontrollitoimista [Lay confidence in Finnish health authorities and opinions of control measures regarding the SARS outbreak]. Suomen Lääkärilehti 2004; 47:4629-33. 
GSP Genomics, Society and Policy

online 2009, Vol.5, No.2, pp.67-79

${ }^{28}$ A. Kouvo and T. Kankainen. Sosiaalista pääomaa rakentamassa vai purkamassa? Suomalaiset hyvinvointipalvelut ja yleistynyt luottamus [Building or eroding social capital? Finnish welfare state institutions and generalized trust]. Yhteiskuntapolitiikka 2009; 74:585-603.

${ }^{29}$ Critchley, op. cit. note 12 .

${ }^{30}$ A. Tupasela and K. Snell. National interests vs. international collaboration: opinions of Finns towards usages of tissue samples. Bioethics. Submitted manuscript.

${ }^{31}$ Treweek et al., op. cit. note 18 .

${ }^{32} \mathrm{O}$. Corrigan and R. Tutton. What's in a name? Subjects, volunteers, participants and activists in clinical research. Clin Ethics 2006; 1(2):101-4.

Genomics, Society and Policy, Vol.5, No.2 (2009) ISSN: 1746-5354

(C) ESRC Genomics Network. 